\title{
Treatment of Palm Oil Mill Effluent by a Microbial Consortium Developed from Compost Soils
}

\author{
Charles O. Nwuche, ${ }^{1,2}$ Hideki Aoyagi, $^{2}$ and James C. Ogbonna ${ }^{1}$ \\ ${ }^{1}$ Department of Microbiology, University of Nigeria, Nsukka 410001, Nigeria \\ ${ }^{2}$ Department of Bioscience and Bioengineering, Graduate School of Life and Environmental Sciences, University of Tsukuba, \\ Tennodai 1-1-1, Tsukuba-shi, Ibaraki 305-8572, Japan
}

Correspondence should be addressed to Charles O. Nwuche; charles.nwuche@unn.edu.ng

Received 21 August 2014; Accepted 7 October 2014; Published 29 October 2014

Academic Editor: David Rodríguez-Lázaro

Copyright (C) 2014 Charles O. Nwuche et al. This is an open access article distributed under the Creative Commons Attribution License, which permits unrestricted use, distribution, and reproduction in any medium, provided the original work is properly cited.

A method for the aerobic treatment of palm oil mill effluent (POME) was investigated in shake-flask experiments using a consortium developed from POME compost. POME was initially centrifuged at 4,000 g for $15 \mathrm{~min}$ and the supernatant was enriched with $\left(\mathrm{NH}_{4}\right)_{2} \mathrm{SO}_{4}(0.5 \%)$ and yeast extract $(0.25 \%)$ to boost its nitrogen content. At optimum $\mathrm{pH}(\mathrm{pH} 4)$ and temperature $\left(40^{\circ} \mathrm{C}\right)$ conditions, the chemical oxygen demand (COD) of the effluent decreased from 10,350 to 1,000 mg/L (90.3\%) after 7 days. The total bacterial population determined by plate count enumeration was $2.4 \times 10^{6} \mathrm{CFU} / \mathrm{mL}$, while the fungal count was $1.8 \times 10^{3}$ colonies/mL. Bacteria of the genera Pseudomonas, Flavobacterium, Micrococcus, and Bacillus were isolated, while the fungal genera included Aspergillus, Penicillium, Trichoderma, and Mucor. When the isolated species were each inoculated into separate batches of the raw effluent, both $\mathrm{pH}$ and COD were unchanged. However, at 75 and 50\% POME dilutions, the COD dropped by 52 and $44 \%$, respectively, while the $\mathrm{pH}$ increased from 4 to 7.53 . POME treatment by aerobic method is sustainable and holds promising prospects for cushioning the environment from the problems associated with the use of anaerobic systems.

\section{Introduction}

Palm oil mill effluent (POME) is an acidic, viscous, and voluminous colloidal suspension formed during palm oil processing from the mixed stream of sterilizer condensate, separator sludge, and hydrocyclone wastewater [1]. Depending on the method of processing, it is composed of 95$96 \%$ water, $0.6-0.7 \%$ oil, and $4-5 \%$ total solids [2]. POME is a highly polluting wastewater and causes considerable deterioration of soil and water quality when discharged untreated into the environment [3]. Recently, the enforcement of stringent laws pertaining to waste effluent discharges in some palm oil producing communities in Nigeria have challenged researchers to investigate new approaches for the effective management of POME.

Several physicochemical techniques such as adsorption [4], solvent extraction [2], chemical-biological sedimentation [5], coagulation-flocculation [6], and membrane technology [7] have been applied in mitigating the polluting effects of POME but the reported outcomes have not produced acceptable results. Biological treatment methods, especially ponding, are the most common treatment system implemented perhaps due to their low capital cost [8] but the effectiveness of these methods is plagued by several drawbacks such as long retention time and start-up periods, necessity for large digesters, sensitivity of microorganisms to variations in environmental conditions, and the emission of corrosive and odorous biogas [9].

Currently, microorganisms used for the treatment of POME and other oil processing wastes have mainly been single species $[10,11]$. However, due to differences in the characteristics of most effluents, it could be difficult for one organism to metabolize all the polluting components to acceptable discharge characteristic [12]. Microbial monocultures metabolise only a limited range of substrates but a mixed microbial community may be more efficient for treatment or remediation due to their broad enzymatic capacities [13]. In the anaerobic (ponding) method of POME treatment 
for instance, different populations of microorganisms are mobilized in a succession of distinct biochemical phases to bring about higher COD removal than any of the individual component species could achieve [14]. The use of mixed cultures in biodegradation studies has numerous advantages which include higher tolerance to perturbations such as changes in nutrient, $\mathrm{pH}$, temperature, and pollutant concentrations [15].

The practice of diluting effluents with water prior to treatment is common but it increases the effluent volume several folds making it not only challenging and expensive to handle but significantly heightens the risk of environmental damage through seepage into water and soil microhabitats. Presently, modern treatment methods require some form of concentration as a prestep before appropriate treatment strategy is implemented. Although the use of a single organism in the aerobic treatment of POME has been reported [10], there still exists paucity of scientific information on the application of mixed cultures. In the present study, therefore, a method for the treatment of POME using a microbial consortium developed from compost soil is presented.

\section{Materials and Methods}

2.1. Palm Oil Mill Effluent (POME). POME used in the present study was obtained fresh from a local palm oil processing mill at Nsukka, Enugu State, Nigeria. It was shaken in a $1 \mathrm{~L}$ measuring cylinder for $30 \mathrm{~s}$ and then kept for $1 \mathrm{~h}$ to allow for sedimentation of solids. Subsequently, the effluent was centrifuged at 4,000 g for $15 \mathrm{~min}$ for total elimination of solids. The resulting supernatant was distributed into $500 \mathrm{~mL}$ Erlenmeyer flasks. Prior to inoculation, each $100 \mathrm{~mL}$ volume was supplemented with $0.5 \%\left(\mathrm{NH}_{4}\right)_{2} \mathrm{SO}_{4}$ and $0.25 \%$ yeast extract. The medium was sterilized at $121^{\circ} \mathrm{C}$ for $15 \mathrm{~min}$ at 15 psi.

2.2. Isolation and Identification of Microorganisms. For the enumeration of the microbial populations, serial tenfold dilutions were made on supernatants from the compost suspension. Aliquots of $100 \mu \mathrm{L}$ were taken from both low and high dilutions and spread inoculated over the surfaces of replicate sterile plates of nutrient agar and potato dextrose agar (PDA) for the growth of bacterial and fungal colonies, respectively. After $48 \mathrm{~h}$ at $37^{\circ} \mathrm{C}$, bacterial colonies were counted while the fungal cultures were kept at $30^{\circ} \mathrm{C}$ for 4-5 days. Emerging discrete colonies were streaked onto new agar plates in order to isolate each strain in pure culture. Genotypic identification was done based on Bergey's Manual of Systemic Bacteriology. For the fungal isolates, micromorphological features were compared against the genus descriptions of Hoog et al. [16].

2.3. Nitrogen Sources. Various nitrogen containing inorganic and organic compounds were examined for their effect on the rate of COD reduction by the inoculated cultures. The method employed was to substitute $\left(\mathrm{NH}_{4}\right)_{2} \mathrm{SO}_{4}$ for $\mathrm{KNO}_{3}$, $\mathrm{NH}_{4} \mathrm{NO}_{3}, \mathrm{CO}\left(\mathrm{NH}_{2}\right)_{2}, \mathrm{NH}_{4} \mathrm{Cl}$, peptone, or yeast extract in the medium while maintaining other factors constant. For the purpose of this experiment, the usual yeast extract supplementation was excluded.

2.4. Effect of Individual Species on COD Reduction. The isolated organisms were inoculated into separate batches of POME to examine their impact on the COD of the effluent. Bacterial cultures were propagated in freshly prepared nutrient broth (Lab M) by inoculation of 1 loopful of each strain into $100 \mathrm{~mL}$ medium. Incubation was carried out at $30^{\circ} \mathrm{C}$ to a final cell concentration of $10^{7} \mathrm{CFU} / \mathrm{mL}$. As previously indicated, the medium was centrifuged, and the pellets were washed twice in sterile saline and resuspended in a $5 \mathrm{~mL}$ volume before inoculating the POME medium. The fungal spores were transferred aseptically onto sterile surfaces of freshly prepared PDA plates and incubated for 5 days. Thereafter, the surfaces of the plates were flooded with $5 \mathrm{~mL}$ of distilled water and scrapped gently by a sterilized inoculating needle to dislodge the fungal spores from the mycelia fragments. The suspension was transferred to a clean receptacle. The pooled spore suspension was centrifuged at $4,000 \mathrm{~g}$ for $10 \mathrm{~min}$, washed, and resuspended in another $5 \mathrm{~mL}$ of distilled water. The concentrated spore suspension was then used to inoculate a POME medium after adjusting the spore density to $1.0 \times 10^{7}$ spores $/ \mathrm{mL}$ with the aid of a Neubauer haemocytometer. Fermentation was conducted for a total of 7 days as previously indicated.

2.5. Development of the Mixed Culture Inoculum. Materials from POME composts (dump sites) were collected from ten random locations at $5-15 \mathrm{~cm}$ depth using a $2.5 \mathrm{~cm}$ soil auger. The samples were carried inside sterile labeled polyethylene plastic bags protected from direct sunlight and transported to the laboratory for further processing. On arrival, $5 \mathrm{~g}$ of the homogenized sample was transferred to a $250 \mathrm{~mL}$ Erlenmeyer flask containing $45 \mathrm{~mL}$ of sterile physiological saline (PS; Oxoid). The flask was agitated in a shaker at $100 \mathrm{rpm}$ for $2 \mathrm{~h}$ at $26 \pm 2^{\circ} \mathrm{C}$ to dissolve clumps and disperse organic materials. The solid suspension was centrifuged at $1,500 \mathrm{~g}$ for $15 \mathrm{~min}$ and the supernatant $(10 \%)$ was inoculated into a previously sterilized and cooled mineral salts medium (MSM) composed of (g/L) $\left(\mathrm{NH}_{4}\right)_{2} \mathrm{SO}_{4}$ (5), $\mathrm{Na}_{2} \mathrm{PO}_{4}$ (6), $\mathrm{KH}_{2} \mathrm{PO}_{4}(2), \mathrm{MgSO}_{4}(3), \mathrm{CaCl}_{2} \cdot 2 \mathrm{H}_{2} \mathrm{O}(3)$, and POME $10 \mathrm{~mL}$ as the sole carbon source. The $\mathrm{pH}$ of the medium was adjusted to 4 in line with the $\mathrm{pH}$ of the soil prior to sampling. The medium was enriched through weekly transfers of $10 \%(\mathrm{v} / \mathrm{v})$ of the culture supernatant to a fresh medium over a total of six weeks.

2.6. Microorganisms and Culture Conditions. Flasks in the last acclimation stage were withdrawn and the content of one Erlenmeyer flask was centrifuged at $10,000 \mathrm{~g}$ for $15 \mathrm{~min}$. The microbial pellet formed was washed in normal sterile physiological saline $(0.85 \% \mathrm{NaCl})$ before resuspending in another $5 \mathrm{~mL}$ solution to form the microbial inoculum. The content of the test tube was then emptied into a $500 \mathrm{~mL}$ Erlenmeyer flask containing $95 \mathrm{~mL}$ of the POME. Fermentation was conducted at $100 \mathrm{rpm}, \mathrm{pH} 4$ at $30^{\circ} \mathrm{C}$ for 7 days except otherwise indicated. Samples taken periodically were passed through Millex $0.22 \mu \mathrm{m}$ filters (Millipore SA, France) 
TABLE 1: Characteristics of the different POME treatments used in the study.

\begin{tabular}{|c|c|c|c|c|c|}
\hline Parameters (mg/L) & Raw POME & $\begin{array}{c}\text { POME } \\
\text { supernatant }\end{array}$ & $\begin{array}{c}\text { POME supernatant }+ \\
\left(\mathrm{NH}_{4}\right)_{2} \mathrm{SO}_{4}(0.5 \%)+\text { yeast } \\
\text { extract }(0.25 \%)\end{array}$ & $\begin{array}{l}\text { POME (100\%) after } \\
\text { treatment with single } \\
\text { strain }\end{array}$ & $\begin{array}{l}\text { POME after treatment } \\
\text { with mixed cultures }\end{array}$ \\
\hline $\mathrm{pH}^{*}$ & $3.98 \pm 0.02$ & $3.97 \pm 0.03$ & $4.03 \pm 0.02$ & $4.03 \pm 0.02$ & $7.79 \pm 0.15$ \\
\hline $\begin{array}{l}\text { Oil/grease } \\
(\mathrm{O} \text { and } \mathrm{G})\end{array}$ & $2,800 \pm 300$ & $840 \pm 40$ & $860 \pm 25$ & $530 \pm 18$ & ND \\
\hline COD & $60,400 \pm 784$ & $8,700 \pm 500$ & $10,350 \pm 430$ & $10,360 \pm 350$ & $1,000 \pm 100$ \\
\hline $\begin{array}{l}\text { Total soluble } \\
\text { carbohydrate }\end{array}$ & $4,470 \pm 230$ & $580 \pm 65$ & $660 \pm 30$ & $645 \pm 25$ & $845 \pm 24$ \\
\hline $\begin{array}{l}\text { Total solids } \\
\text { (TS) }\end{array}$ & $27,300 \pm 640$ & ND & $\mathrm{ND}$ & ND & $\mathrm{ND}$ \\
\hline $\begin{array}{l}\text { Total suspended } \\
\text { solids (TSS) }\end{array}$ & $24,000 \pm 690$ & ND & ND & ND & ND \\
\hline Phenol & $100 \pm 00$ & $100 \pm 00$ & $100 \pm 00$ & $100 \pm 00$ & ND \\
\hline $\begin{array}{l}\text { Ammonia } \\
\text { (nitrogen) }\end{array}$ & $410 \pm 20$ & $40 \pm 05$ & $1,250 \pm 85$ & $1,520 \pm 55$ & $780 \pm 20$ \\
\hline Nitrogen (total) & $1,850 \pm 50$ & $110 \pm 07$ & $2,735 \pm 130$ & $2,650 \pm 90$ & $1,920 \pm 75$ \\
\hline Nitrates & $500 \pm 20$ & $90 \pm 04$ & $840 \pm 30$ & $830 \pm 20$ & $750 \pm 30$ \\
\hline
\end{tabular}

ND: not detected.

${ }^{*}$ Not measured in $\mathrm{mg} / \mathrm{L}$.

to eliminate microbial cells and mycelia before analyzing for $\mathrm{COD}$ and $\mathrm{pH}$.

2.7. Optimization of $\mathrm{pH}$ and Temperature Conditions for Consortium Inoculum. The medium was adjusted before sterilization to $\mathrm{pH}$ values of $3,4,5,6$, or 7 using $1 \mathrm{M}$ $\mathrm{H}_{2} \mathrm{SO}_{4}$ and $1 \mathrm{M} \mathrm{NaOH}$. The cultures were inoculated and incubated at $30^{\circ} \mathrm{C}$ for 7 days. Later, media adjusted to the best $\mathrm{pH}$ condition were treated as before and incubated at temperatures of $30,35,40,45$, or $50^{\circ} \mathrm{C}$ for 7 days. The cell free filtrates withdrawn periodically were evaluated for changes in $\mathrm{COD}$ and $\mathrm{pH}$.

2.8. Analytical Methods. The $\mathrm{pH}$, oil and grease (O and G), total solids (TS), and total suspended solids (TSS) were determined by standard methods [17]. Total soluble carbohydrate (TSC) was analyzed by the phenol-sulphuric acid method [18]. Chemical oxygen demand (COD), ammonianitrogen $\left(\mathrm{NH}_{3}-\mathrm{N}\right)$, total nitrogen $(\mathrm{N})$, and nitrates $\left(\mathrm{NO}_{3}{ }^{-}\right)$ were measured by the Hach Spectrophotometric method (DR/4000, Hach Co., Ltd., Tokyo). Phenol was estimated by the phenol test kit (Wako Pure Chemical Ind., Osaka).

2.9. Statistical Analysis. The presented results are the means of triplicate determinations \pm standard deviation. Where applicable, the completely randomized one-way analysis of variance was used to determine the level of significance of the treatments. The statistical software IBM-SPSS (2008 version) was used in the calculations.

\section{Results}

3.1. Characteristics of POME Used in the Study. The major characteristics of POME used in the present study are summarized in Table 1. It had an initial $\mathrm{pH}$ of $3.98 \pm 0.02$ and oil and grease concentration of $2,800 \pm 300 \mathrm{mg} / \mathrm{L}$. The
COD and TSC were $60,400 \pm 784$ and $4470 \pm 230 \mathrm{mg} / \mathrm{L}$, respectively. TS was $27,300 \pm 640 \mathrm{mg} / \mathrm{L}$, while TSS was $24,000 \pm 690 \mathrm{mg} / \mathrm{L}$. Phenol was detected at the concentration of $100 \pm 00 \mathrm{mg} / \mathrm{L}$. Among the nitrogen containing compounds, ammonia (nitrogen) had a concentration of $410 \pm 20 \mathrm{mg} / \mathrm{L}$, while the total nitrogen was $1,850 \pm 50 \mathrm{mg} / \mathrm{L}$. The nitrate concentration was found to be $500 \pm 20 \mathrm{mg} / \mathrm{L}$. When the supernatant of the POME was analyzed after sedimentation, $\mathrm{pH}$ was $3.97 \pm 0.03$ but $\mathrm{O}$ and $\mathrm{G}$ level reduced to $840 \pm 40 \mathrm{mg} / \mathrm{L}$. COD decreased to about $8,700 \pm 500 \mathrm{mg} / \mathrm{L}$, while the TSC concentration dropped to $580 \pm 65 \mathrm{mg} / \mathrm{L}$. Both TS and TSS were nondetectable. Phenol concentration was constant $(100 \pm 00 \mathrm{mg} / \mathrm{L})$ but ammonia nitrogen reduced to $110 \pm 07 \mathrm{mg} / \mathrm{L}$. The concentration of both nitrogen (total) and nitrates dropped to $90 \pm 04$ and $40 \pm 05 \mathrm{mg} / \mathrm{L}$, respectively. Analysis of the final effluent supplemented with both $\left(\mathrm{NH}_{4}\right)_{2} \mathrm{SO}_{4}$ and yeast extract indicates that the $\mathrm{pH}$ increased to $4.04 \pm 0.05$, while $\mathrm{O}$ and $\mathrm{G}$ did not change $(860 \pm 25 \mathrm{mg} / \mathrm{L})$. COD rose to $10,350 \pm 430 \mathrm{mg} / \mathrm{L}$, while the TSC increased marginally to $660 \pm 30 \mathrm{mg} / \mathrm{L}$. Both TS and TSS were not detected but phenol concentration remained $100 \pm 00 \mathrm{mg} / \mathrm{L}$. Nitrogen concentrations were significantly affected by the addition of nitrogen sources. In particular, nitrogen (ammonia) and total nitrogen concentrations were $1,250 \pm 85$ and $2,835 \pm 130 \mathrm{mg} / \mathrm{L}$, respectively, while the concentration of nitrates was $840 \pm 30 \mathrm{mg} / \mathrm{L}$. When the supplemented POME was inoculated with both single strain and mixed cultures in separate batches, significant changes were found when the final effluents were analyzed. Final pH was $4.03 \pm 0.02$ in the single strain treatment but in the mixed cultures, it was $7.79 \pm 0.15$. The concentration of $\mathrm{O}$ and $\mathrm{G}$ in the former was $530 \pm 20 \mathrm{mg} / \mathrm{L}$ but completely eliminated in the latter. COD content of the single strain treatment was $10,360 \pm 350 \mathrm{mg} / \mathrm{L}$. This value decreased to $1,000 \pm$ $100 \mathrm{mg} / \mathrm{L}(90.3 \%)$ in treatment containing the mixed cultures. 
TABLE 2: Enumeration and identification of the adapted microbial populations in the samples.

\begin{tabular}{ll}
\hline Microorganism & Average total count \\
\hline Bacteria & \\
(a) Pseudomonas fluorescens & \\
(b) Flavobacterium sp. & $2.4 \times 10^{6} \mathrm{CFU} / \mathrm{mL}$ \\
(c) Micrococcus sp. & \\
(d) Bacillus subtilis & \\
\hline Fungi & \\
(a) Aspergillus niger & \\
(b) Aspergillus tamari & \\
(c) Aspergillus sp. & \\
(d) Penicillium sp. & \\
(d) Trichoderma sp. & \\
(e) Mucor sp. &
\end{tabular}

One other interesting discovery in this batch was the complete disappearance of phenol even though its initial concentration of $100 \mathrm{mg} / \mathrm{L}$ persisted in the batch treated with a single strain. Results also indicate that the treatments affected the nitrogen content of the effluents significantly $(P<0.05)$. In the single strain treatment, ammonia (nitrogen) concentration was $1,520 \pm 55 \mathrm{mg} / \mathrm{L}$ but this decreased to $780 \mathrm{mg} / \mathrm{L}$ in the mixed culture treatment. There was no significant change in the total nitrogen content of the former (single strain), but in the latter, total nitrogen dropped to $1,920 \pm 30 \mathrm{mg} / \mathrm{L}$. Nitrate concentrations in both effluents were $830 \pm 20 \mathrm{mg} / \mathrm{L}$ and $750 \pm 30 \mathrm{mg} / \mathrm{L}$, respectively.

\subsection{Enumeration of the Microbial Populations and Identifica-} tion of the Adapted Species. Total plate count estimation of the microbial load of the compost samples showed that the bacteria population was $2.4 \times 10^{6} \mathrm{CFU} / \mathrm{mL}$, while fungi were $1.8 \times 10^{3}$ colonies $/ \mathrm{mL}$ (Table 2). However, biochemical identification of the organisms isolated after the adaptation experiments reveals that the bacterial community was composed of four main genera, namely, Pseudomonas, Flavobacterium, Micrococcus, and Bacillus. The species of the Pseudomonas and Bacillus genera isolated were Pseudomonas fluorescens and Bacillus subtilis. Among the isolated fungal genera were Aspergillus, Penicillium, Trichoderma, and Mucor. Aspergillus niger was the most frequently isolated fungus, while Trichoderma was the least.

3.3. Effect of Different Nitrogen Compounds on COD Reduction. Among the range of both organic and inorganic compounds tested (Figure 1), $\left(\mathrm{NH}_{4}\right)_{2} \mathrm{SO}_{4}$ promoted the highest COD removal (65.6\%). Subsequently it was selected as a nitrogen supplement for the medium. Yeast extract and urea had $55 \%$ and $44.5 \%$ removal efficiencies, respectively. $\mathrm{NH}_{4} \mathrm{NO}_{3}$ elicited the least COD decrease (10\%) while with $\mathrm{KNO}_{3}, \mathrm{NaNO}_{3}$, and peptone, less than $20 \%$ COD decrease was achieved.

3.4. Effect of Individual Cultures on COD Reduction. When individual cultures were inoculated into separate batches of the raw POME media, results indicated that the organisms

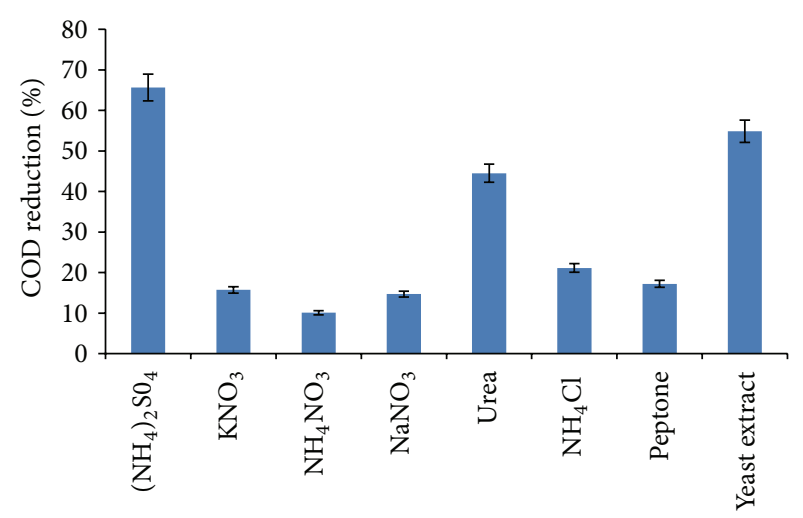

Different inorganic/organic nitrogen compounds.

FIGURE 1: Effect of different nitrogen compounds on COD reduction.

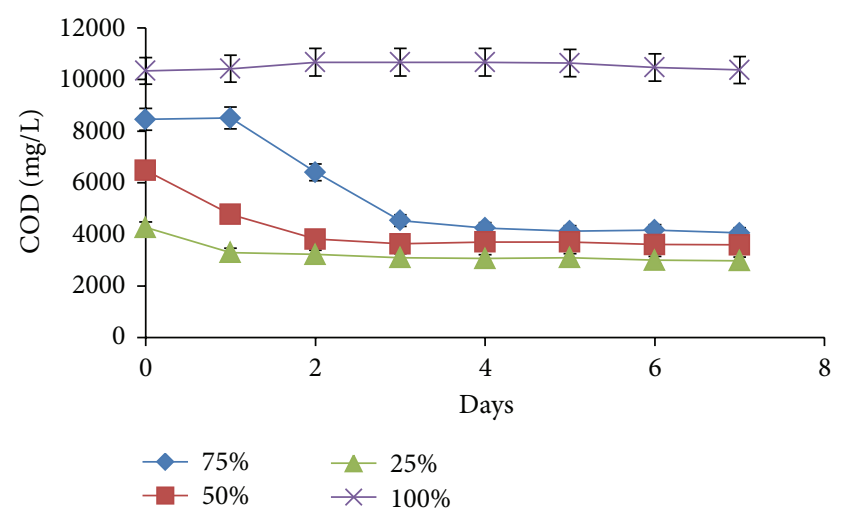

FIgURE 2: Effect of POME concentration on COD changes during treatment by an isolate (Aspergillus sp.).

did not achieve significant reduction in the COD of the effluent (Figure 2). COD decreased between 0 and $0.65 \%$ in media inoculated with both bacterial and fungal strains (data not shown). When different dilutions of the medium were used, significant changes in COD took place. At 75\% POME concentration, COD dropped by $52 \%(8,455$ to $4,055 \mathrm{mg} / \mathrm{L})$ while in the 50 and 25\% POME, COD losses were $44 \%(6,475$ to $3,595 \mathrm{mg} / \mathrm{L})$ and $30 \%(4,265$ to $2,975 \mathrm{mg} / \mathrm{L})$, respectively. As shown in Figure 3, pH was unchanged $(\mathrm{pH} 4)$ in the $100 \%$ POME but at higher dilutions, $\mathrm{pH}$ went slightly beyond the neutral mark. At $75 \%$ concentration, $\mathrm{pH}$ rose after a $36 \mathrm{~h}$ lag to a peak value of 7.43. At other concentrations, $\mathrm{pH}$ values of up to 7.53 were achieved in the 50\% POME while in the 25\% concentration, $\mathrm{pH}$ reached 7.13.

3.5. Effect of $p H$ and Temperature Changes on COD Kinetics. As fermentation progressed to 3rd day, COD in the effluents of $\mathrm{pH} 4$ dropped to $3,640 \mathrm{mg} / \mathrm{L}$ (64\%) while in the samples adjusted to $\mathrm{pH} 3,46 \%(5,540 \mathrm{mg} / \mathrm{L})$ decrease was achieved (Figure 4). By the 6th day, COD had reduced to $1,500 \mathrm{mg} / \mathrm{L}$ at $\mathrm{pH} 4$, representing $85.5 \%$ reduction. On the other hand, at $\mathrm{pH} 3$, the COD decreased steadily up to the 7 th day with a total loss of $77 \%(7,985 \mathrm{mg} / \mathrm{L})$. COD kinetics at both $\mathrm{pH}$ 5 and 6 showed that COD dropped to $9,100 \mathrm{mg} / \mathrm{L}$ (12\%) but 


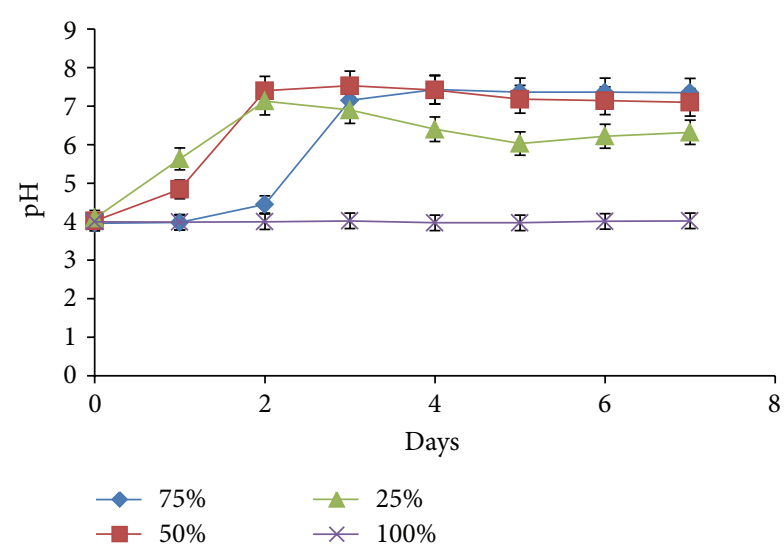

Figure 3: Effect of POME concentration on $\mathrm{pH}$ changes during treatment by an isolate (Aspergillus sp.).

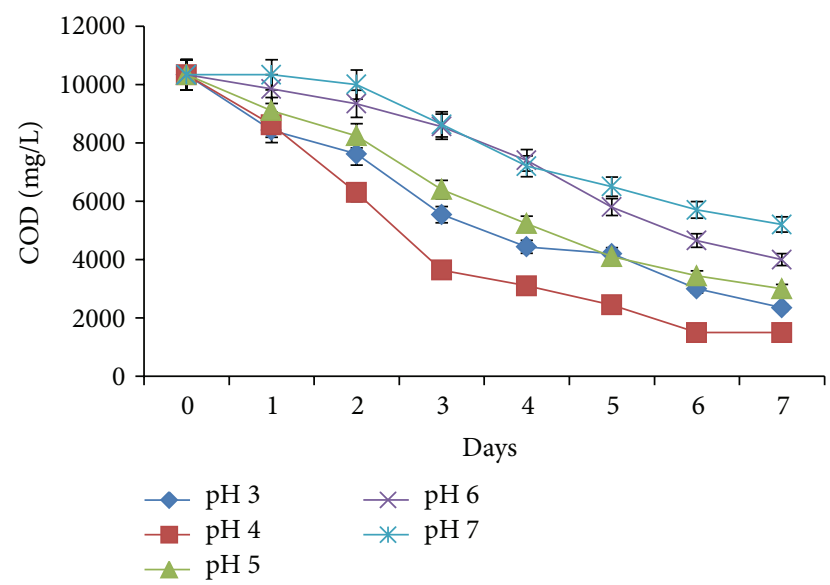

Figure 4: Effect of $\mathrm{pH}$ on COD of the effluent during treatment.

at $\mathrm{pH} 6$, only $4.47 \%$ reduction was achieved. By the 3 rd day, nearly $40 \%(3,925 \mathrm{mg} / \mathrm{L})$ of the COD had been removed at $\mathrm{pH} 5$ while only $17 \%(1,757 \mathrm{mg} / \mathrm{L})$ was lost at $\mathrm{pH}$. Total COD losses at both $\mathrm{pH}$ (5 and 6) conditions were 71 and $61 \%$, respectively. At $\mathrm{pH} 7, \mathrm{COD}$ was unchanged after $48 \mathrm{~h}$ but by the $3 \mathrm{rd}$ day, $16.5 \%(1,705 \mathrm{mg} / \mathrm{L})$ of the COD had been removed. By the 7 th day, approximately $50 \%(5,200 \mathrm{mg} / \mathrm{L})$ of the organic load had been removed.

Temperature also had significant effect on the COD changes in the medium (Figure 5). At 30 and $35^{\circ} \mathrm{C}$, the total COD removal was $80.6 \%(8,335 \mathrm{mg} / \mathrm{L})$ and $86.5 \%$ $(8,935 \mathrm{mg} / \mathrm{L})$, respectively. At $40^{\circ} \mathrm{C}$, the COD dropped rapidly to $4,150 \mathrm{mg} / \mathrm{L}(60 \%)$ within 2 days and further to $1,600 \mathrm{mg} / \mathrm{L}$ $(84.5 \%)$ by the 4 th day and finally to $1,000 \mathrm{mg} / \mathrm{L}(90.3 \%)$ by the 5th day. Afterwards, COD was stable until the end of the treatments. The rates of COD reduction at 45 and $50^{\circ} \mathrm{C}$ were lower than those observed at lower temperatures. Initially, a lag appeared before measurable changes in COD were observed. At $45^{\circ} \mathrm{C}$, the lag lasted for $24 \mathrm{~h}$ but at $50^{\circ} \mathrm{C}$, it took longer than $48 \mathrm{~h}$ before cultures could become metabolically active. Despite the initial delays, total COD decrease at $45^{\circ} \mathrm{C}$ was $63 \%(6,535 \mathrm{mg} / \mathrm{L})$, while at $50^{\circ} \mathrm{C}, 54 \%(5,585 \mathrm{mg} / \mathrm{L}) \mathrm{COD}$ was lost.

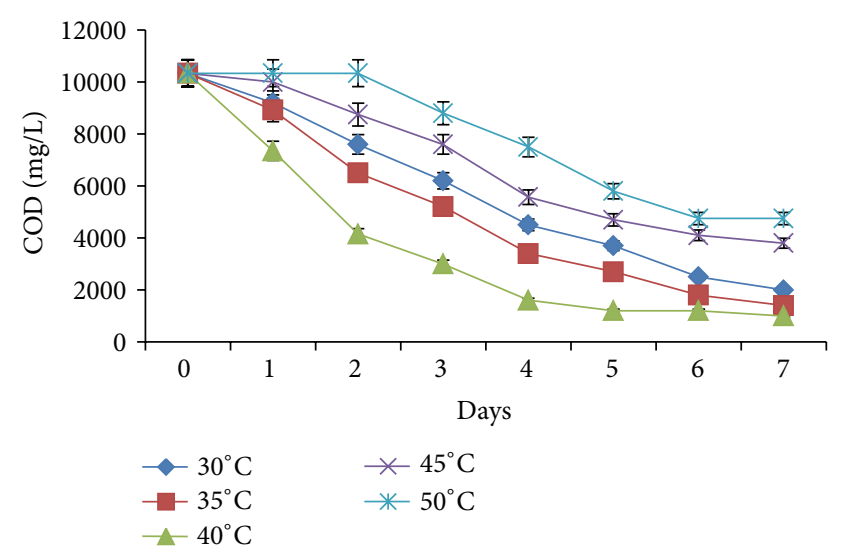

FIGURE 5: Effect of temperature on COD of the effluent during treatment.

\section{Discussion}

4.1. Characteristics of POME Used in the Study. The sedimentation process resulted in significant $(P<0.05)$ reduction in the major pollution indices of the wastewater (Table 1). $\mathrm{O}$ and $\mathrm{G}$, for instance, decreased by $70 \%(2,800$ to $840 \mathrm{mg} / \mathrm{L})$. The COD and TSC dropped by $85.6 \%(60,400$ to $8,700 \mathrm{mg} / \mathrm{L})$ and $86.9 \%(4,470$ to $580 \mathrm{mg} / \mathrm{L})$, respectively, while both the TS and TSS were completely eliminated. The sediments or sludge is composed of lignocelluloses and other polysaccharides [19] and may be processed into biohydrogen [20], fertilizers [21], enzymes [22], and citric acid [23]. Nitrogen is present in POME in organic (protein) forms but with time, the organic nitrogen converts to ammonia [24]. Sedimentation also diminished the nitrogen content of the POME even further. However, supplementation with ammonium sulphate and yeast extract provided adequate supplies of the required compounds. In treatments containing separate batches of both single and mixed cultures, it was found that the mixed populations promoted higher COD removal than the single strain. The $\mathrm{pH}$ of the final effluent $(7.79 \pm 0.15)$ was also found to be within the acceptable discharge limit for treated effluents. Although significant concentration of $\mathrm{O}$ and $\mathrm{G}$ was found after treatment with the single strain $(530 \pm 20 \mathrm{mg} / \mathrm{L})$, it was completely metabolized in the batch containing mixed cultures. The increase in the concentration of TSC (845 \pm $24 \mathrm{mg} / \mathrm{L}$ ) might result from the accumulation of glycerol following the enzymatic hydrolysis of oils in the wastes. Supplementation with ammonium sulphate and yeast extract boosted the nitrogen content of the effluent. However, after treatment with the mixed cultures, the compounds decreased substantially unlike the single strain treatment.

4.2. Enumeration of the Microbial Populations and Identification of the Adapted Species. A total of four bacterial and five fungal genera were isolated (Table 2). Their compositions and density were identical to previous report by Ugoji [25] on POME microflora. Of the four bacterial isolates, B. subtilis was the most frequently isolated (data not shown). The high temperature of the compost environment may have promoted the domination of the Bacillus strains over the other 
bacterial genera. Bacillus has been widely isolated during the thermophilic stages of composting [26]. In addition, the frequency of isolation of $P$. fluorescens and $B$. subtilis might be connected with the abundance of cellulose in the waste. Cellulose is dominant in plant materials found in POME composts and both organisms have been shown to be good cellulase producers [27]. Equally, the lipase producing property of $P$. fluorescens has been acknowledged [28]. Among the isolated fungi, Trichoderma sp. has been widely studied for cellulase production [29]. Members of the Aspergillus genera were found to be more prominent than the other moulds. The versatility of members of this group might explain their preponderance and domination in virtually any habitat [30]. Aspergillus, Penicillium, and Mucor are among the most reported genera of lipase-producing filamentous fungi [31].

4.3. Effects of Different Nitrogen Compounds. Oil mill effluents do not contain sufficient nitrogen and phosphorus compounds for an effective aerobic treatment process [11]. Therefore, adequate supplementation has to be made in order to satisfy the nutritional requirement of the metabolizing microbiota. In the present study, $\left(\mathrm{NH}_{4}\right)_{2} \mathrm{SO}_{4}$ was found to have promoted the highest rate of COD removal $(65.6 \%)$ and was therefore selected. Several previous reports have highlighted the need for the addition of nitrogen compounds to boost the rate of remediation or treatment. Scioli and Vollaro [32] used $0.6 \%\left(\mathrm{NH}_{4}\right)_{2} \mathrm{SO}_{4}$ and $0.1 \%$ yeast extract in the treatment of olive oil effluent by Yarrowia lipolytica. In the absence or inadequate nitrogen supplementation, COD removal can be as low as $1.47 \%$ [11] and this may make the biological process unfeasible and uneconomical.

4.4. Effect of Individual Species on COD Kinetics. At lower POME concentrations, the organisms achieved significant $(P<0.05)$ reduction in the COD of the effluent but were unable to metabolize the full strength wastewater (Figures 2 and 3). The activities of the different strains were found to be limited, perhaps due to the presence of inhibitory components such as phenol, flavonoids, and alkaloids [33]. These compounds are known to be present in POME and have been reported to display both antibiotic and phytotoxic properties [34]. However, the mixed microbial populations were not negatively affected perhaps due to their wider enzymatic potentials and proven tolerance to high pollutant concentrations [15]. Dilution has been shown to reduce the impact of these compounds, enabling the microbes to thrive and metabolize the organic materials present in the effluent. Although dilution is seen as an option, it results in increase in the volume of the effluent creating a requirement for larger spaces and equipment and making the treatment efforts more laborious and capital intensive. Also, data obtained from treatment at diluted concentrations were statistically $(P<0.05)$ lower than treating the raw POME with a community of organisms. It is noteworthy though that the effects observed with respect to the use of the consortium are not due to the isolated species alone because less than $10 \%$ of all microorganisms are cultivable [35].
4.5. Optimization of $p H$ and Temperature. In the present study, both $\mathrm{pH}$ and temperature conditions (Figures 4 and 5) were found to affect the efficiency of POME treatment in line with previous studies by Kwapisz et al. [36]. The $\mathrm{pH} 4$ was found to be the optimum $\mathrm{pH}$ for $\mathrm{COD}$ reduction. This value is identical to most POME which is usually low due to accumulation of fatty acids [37]. Although $\mathrm{pH} 4$ was the optimum $\mathrm{pH}$ value, COD decrease was substantial at both lower and higher $\mathrm{pH}$ conditions.

The variations in temperature equally resulted in a spectrum of COD changes. At $40^{\circ} \mathrm{C}$, total COD reduction was the highest (92\%) with value getting as low as $1,000 \mathrm{mg} / \mathrm{L}$. At higher temperatures, COD reduction declines due to decrease in the metabolism of cultures as a result of denaturation of key proteins [38]. Although the decrease in COD dropped at $50^{\circ} \mathrm{C}$ to less than $54 \%$, yet treatment was substantial even at such high temperature. This finding is noteworthy because since the system was operated by thermotolerant organisms, the requirement for cooling was found not to be necessary. Yu et al. [39] reported that operating a flow reactor at $55^{\circ} \mathrm{C}$ achieved higher substrate degradation rate, biogas production rate, and specific rate of aqueous product formation than when operated at $37^{\circ} \mathrm{C}$.

\section{Conclusion}

The use of a microbial consortium in the aerobic treatment of POME was investigated in the present study. At optimum conditions, the organisms were found to be more beneficial for large-scale remediation process than any of the constituting individual species. The absence of the requirement for dilution coupled with the ability of the microbes to overcome the growth and metabolic challenges imposed by the presence of inhibitory components in the raw POME highlights the potential value of this method for the treatment of the effluent or remediation of environment polluted by the oil processing waste. Research efforts are presently ongoing to scale up the process from the shaker-flask experiments into pilot scale bioreactor.

\section{Conflict of Interests}

The authors declare that there is no conflict of interests regarding the publication of this paper.

\section{Acknowledgments}

Funding for this research was provided by the Tertiary Education Trust Fund (TETFUND) of the Federal Republic of Nigeria to Charles O. Nwuche. Charles O. Nwuche is grateful to Mr. Takashi Ishihara for assistance rendered during his tenure as visiting foreign research fellow to the University of Tsukuba, Japan.

\section{References}

[1] R. Borja, C. J. Banks, and E. Sánchez, "Anaerobic treatment of palm oil mill effluent in a two-stage up-flow anaerobic sludge 
blanket (UASB) system," Journal of Biotechnology, vol. 45, no. 2, pp. 125-135, 1996.

[2] A. L. Ahmad, S. Ismail, and S. Bhatia, "Water recycling from palm oil mill effluent (POME) using membrane technology," Desalination, vol. 157, no. 1-3, pp. 87-95, 2003.

[3] A. N. Ma, "Environmental management for the palm oil industry," Palm Oil Development, vol. 30, pp. 1-9, 2000.

[4] A. Ariffin, R. S. A. Shatat, A. R. Nik Norulaini, and A. K. Mohd Omar, "Synthetic polyelectrolytes of varying charge densities but similar molar mass based on acrylamide and their applications on palm oil mill effluent treatment," Desalination, vol. 173, no. 3, pp. 201-208, 2005.

[5] F. J. Rivas, O. Beltrán F.J.Gimeno, and P. Alvarez, "Chemicalbiological treatment of table olive manufacturing wastewater," Journal of Environmental Engineering, vol. 127, no. 7, pp. 611-619, 2001.

[6] A. L. Ahmad, S. Sumathi, and B. H. Hameed, "Coagulation of residue oil and suspended solid in palm oil mill effluent by chitosan, alum and PAC," Chemical Engineering Journal, vol. 118, no. 1-2, pp. 99-105, 2006.

[7] A. L. Ahmad, M. F. Chong, S. Bhatia, and S. Ismail, "Drinking water reclamation from palm oil mill effluent (POME) using membrane technology," Desalination, vol. 191, no. 1-3, pp. 3544, 2006.

[8] S. L. Tong and A. Bakar Jaafar, "Waste to energy: methane recovery from anaerobic digestion of palm oil mill effluent," Energy Smart, vol. 4, pp. 1-8, 2004.

[9] S. Yacob, M. Ali Hassan, Y. Shirai, M. Wakisaka, and S. Subash, "Baseline study of methane emission from anaerobic ponds of palm oil mill effluent treatment," Science of the Total Environment, vol. 366, no. 1, pp. 187-196, 2006.

[10] N. Oswal, P. M. Sarma, S. S. Zinjarde, and A. Pant, "Palm oil mill effluent treatment by a tropical marine yeast," Bioresource Technology, vol. 85, no. 1, pp. 35-37, 2002.

[11] R. Lanciotti, A. Gianotti, D. Baldi et al., "Use of Yarrowia lipolytica strains for the treatment of olive mill wastewater," Bioresource Technology, vol. 96, no. 3, pp. 317-322, 2005.

[12] N. Asses, L. Ayed, H. Bouallagui, I. Ben Rejeb, M. Gargouri, and M. Hamdi, "Use of Geotrichum candidum for olive mill wastewater treatment in submerged and static culture," Bioresource Technology, vol. 100, no. 7, pp. 2182-2188, 2009.

[13] L. N. Britton, "Microbial degradation of aliphatic hydrocarbons," in Microbial Degradation of Organic Compounds, D. T. Gibson, Ed., pp. 89-129, Marcel Dekker, New York, NY, USA, 1984.

[14] W. Choorit and P. Wisarnwan, "Effect of temperature on the anaerobic digestion of palm oil mill effluent," Electronic Journal of Biotechnology, vol. 10, no. 3, pp. 376-385, 2007.

[15] R. Boopathy, "Factors limiting bioremediation technologies," Bioresource Technology, vol. 74, no. 1, pp. 63-67, 2000.

[16] G. S. Hoog, J. Guarro, J. Gene, and M. J. Figueras, "Hyphomycetes: explanatory chapters and keys to the genera," in Atlas of Clinical Fungi, G. S. Hoog, J. Gene, and M. J. Figueras, Eds., pp. 361-1008, Central Bureau voor Schimmel Cultures, Netherlands and Universitat Rovira Virgili, Spain Press, 2nd edition, 2000.

[17] Standard Methods for the Examination of Water and Waste Water, American Public Health Association (APHA), American Water Works Association (AWWA) and Water Environment Federation (WEF), Washington, DC, USA, 2005.

[18] M. Dubois, K. A. Gilles, J. K. Hamilton, P. A. Rebers, and F. Smith, "Colorimetric method for determination of sugars and related substances," Analytical Chemistry, vol. 28, no. 3, pp. 350356, 1956.

[19] G. S. Kwon, B. H. Kim, and A. S. H. Ong, "Studies on the utilization of palm oil residues as the substrate for butanol fermentation," Elaeis, vol. 1, pp. 91-102, 1989.

[20] M. S. Kim and D. Y. Lee, "Fermentative hydrogen production from tofu-processing waste and anaerobic digester sludge using microbial consortium," Bioresource Technology, vol. 101, supplement, no. 1, pp. S48-S52, 2010.

[21] P. O. Oviasogie and A. E. Aghimien, "Macronutrient status and speciation of $\mathrm{Cu}, \mathrm{Fe}, \mathrm{Zn}$ and $\mathrm{Pb}$ in soil containing palm oil mill effluent," Global Journal of Pure and Applied. Sciences, vol. 9, pp. 71-80, 2003.

[22] J. I. Daoud and Z. Alam, "Statistical optimization of fermentation conditions for cellulase production from palm oil mill effluent," American Journal of Environmental Sciences, vol. 6, no. 1, pp. 66-70, 2010.

[23] C. O. Nwuche, H. Aoyagi, and J. C. Ogbonna, "Citric acid production from cellulase-digested palm oil mill effluent," Asian Journal of Biotechnology, vol. 5, pp. 51-60, 2013.

[24] M. C. Chow, Palm Oil Mill Effluent Analysis, Palm Oil Research Institute of Malaysia, Kuala-Lumpur, Malaysia, 1991.

[25] E. O. Ugoji, "Anaerobic digestion of palm oil mill effluent and its utilization as fertilizer for environmental protection," Renewable Energy, vol. 10, no. 2-3, pp. 291-294, 1997.

[26] D. M. Charbonneau, F. Meddeb-Mouelhi, M. Boissinot, M. Sirois, and M. Beauregard, "Identification of thermophilic bacterial strains producing thermotolerant hydrolytic enzymes from manure compost," Indian Journal of Microbiology, vol. 52, no. 1, pp. 41-47, 2012.

[27] S. Sethi, A. Datta, B. L. Gupta, and S. Gupta, "Optimization of cellulase production from bacteria isolated from soil," ISRN Biotechnology, vol. 2013, Article ID 985685, 7 pages, 2013.

[28] J. L. Arpigny and K.-E. Jaeger, "Bacterial lipolytic enzymes: classification and properties," Biochemical Journal, vol. 343, no. 1, pp. 177-183, 1999.

[29] J. P. Andrade, A. S. D. R. Bispo, P. A. S. Marbach, and R. P. Do Nascimento, "Production and partial characterization of cellulases from Trichoderma sp. IS-05 isolated from Sandy Coastal plains of Northeast Brazil," Enzyme Research, vol. 2011, Article ID 167248, 7 pages, 2011.

[30] F. J. Contesini, D. B. Lopes, G. A. MacEdo, M. D. G. Nascimento, and P. D. O. Carvalho, "Aspergillus sp. lipase: potential biocatalyst for industrial use," Journal of Molecular Catalysis B: Enzymatic, vol. 67, no. 3-4, pp. 163-171, 2010.

[31] E. Hita, A. Robles, B. Camacho et al., "Production of structured triacylglycerols by acidolysis catalyzed by lipases immobilized in a packed bed reactor," Biochemical Engineering Journal, vol. 46, no. 3, pp. 257-264, 2009.

[32] C. Scioli and L. Vollaro, "The use of Yarrowia lipolytica to reduce pollution in olive mill wastewaters," Water Research, vol. 31, no. 10, pp. 2520-2524, 1997.

[33] N. Wattanapenpaiboon and M. L. Wahlqvist, "Phytonutrient deficiency: the place of palm fruit," Asia Pacific Journal of Clinical Nutrition, vol. 12, no. 3, pp. 363-368, 2003.

[34] A. Uzel, K. Sorkun, Ö. Önçağ, D. Çoğulu, Ö. Gençay, and B. Salih, "Chemical compositions and antimicrobial activities of four different Anatolian propolis samples," Microbiological Research, vol. 160, no. 2, pp. 189-195, 2005.

[35] A. Frostegard and E. Baath, "The use of phospholipid fatty acid analysis to estimate bacterial and fungal biomass in soil," Biology and Fertility of Soils, vol. 22, no. 1-2, pp. 59-65, 1996. 
[36] E. Kwapisz, J. Wszelaka, O. Marchut, and S. Bielecki, "The effect of nitrate and ammonium ions on kinetics of diesel oil degradation by Gordonia alkanivorans S7," International Biodeterioration and Biodegradation, vol. 61, no. 3, pp. 214-222, 2008.

[37] S. J. Santosa, "Palm oil boom in Indonesia: from plantation to downstream products and biodiesel," Clean-Soil, Air, Water, vol. 36, no. 5-6, pp. 453-465, 2008.

[38] B. E. Rittmann and P. L. Mccarty, Environmental Biotechnology: Principles and Applications, McGraw-Hill, New York, NY, USA, 2001.

[39] H. Yu, H. P. Fang, and G. W. Go, "Comparative performance of mesophilic and thermophilic acidogenic upflow reactors," Process Biochemistry, vol. 38, no. 3, pp. 447-454, 2002. 

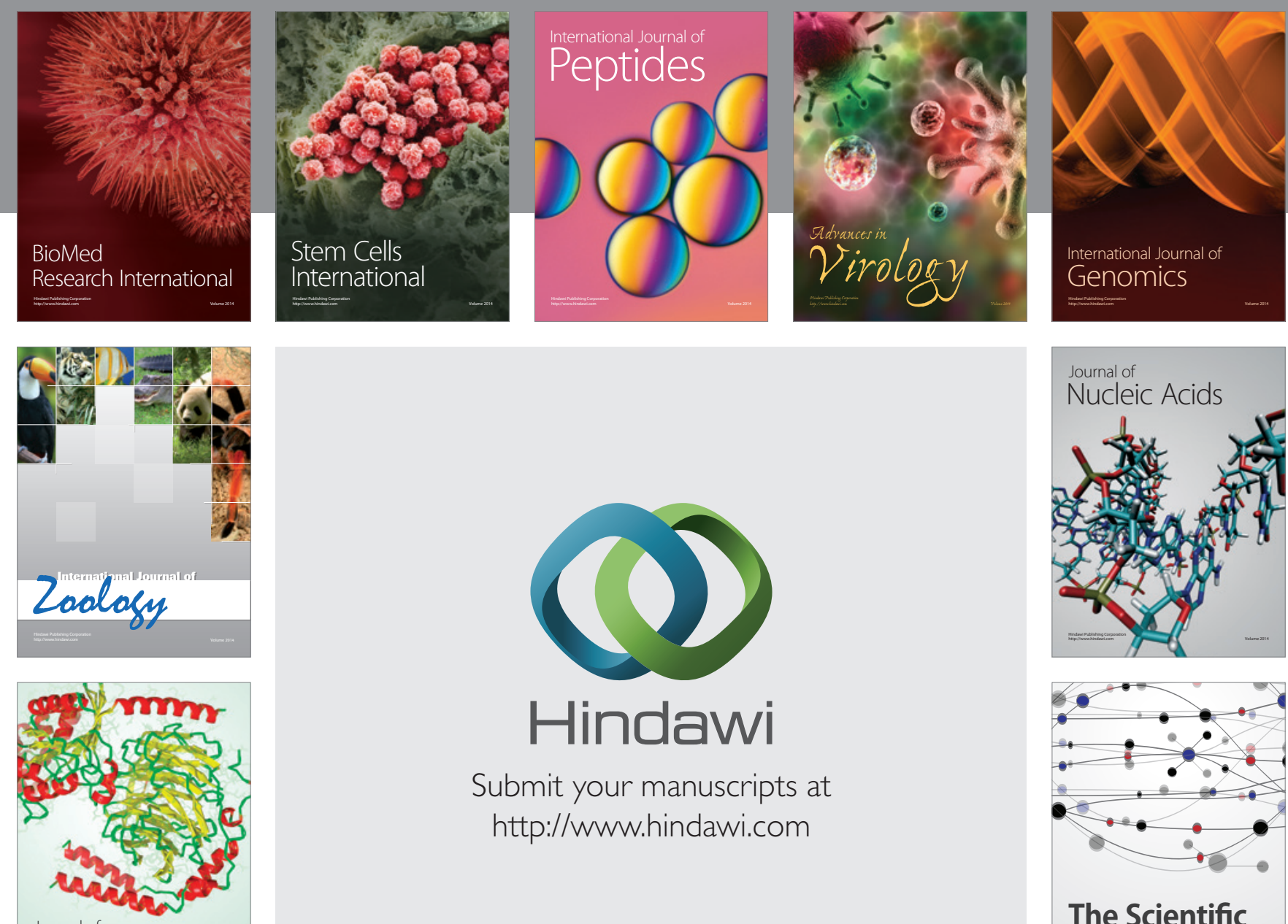

Submit your manuscripts at

http://www.hindawi.com

Journal of
Signal Transduction
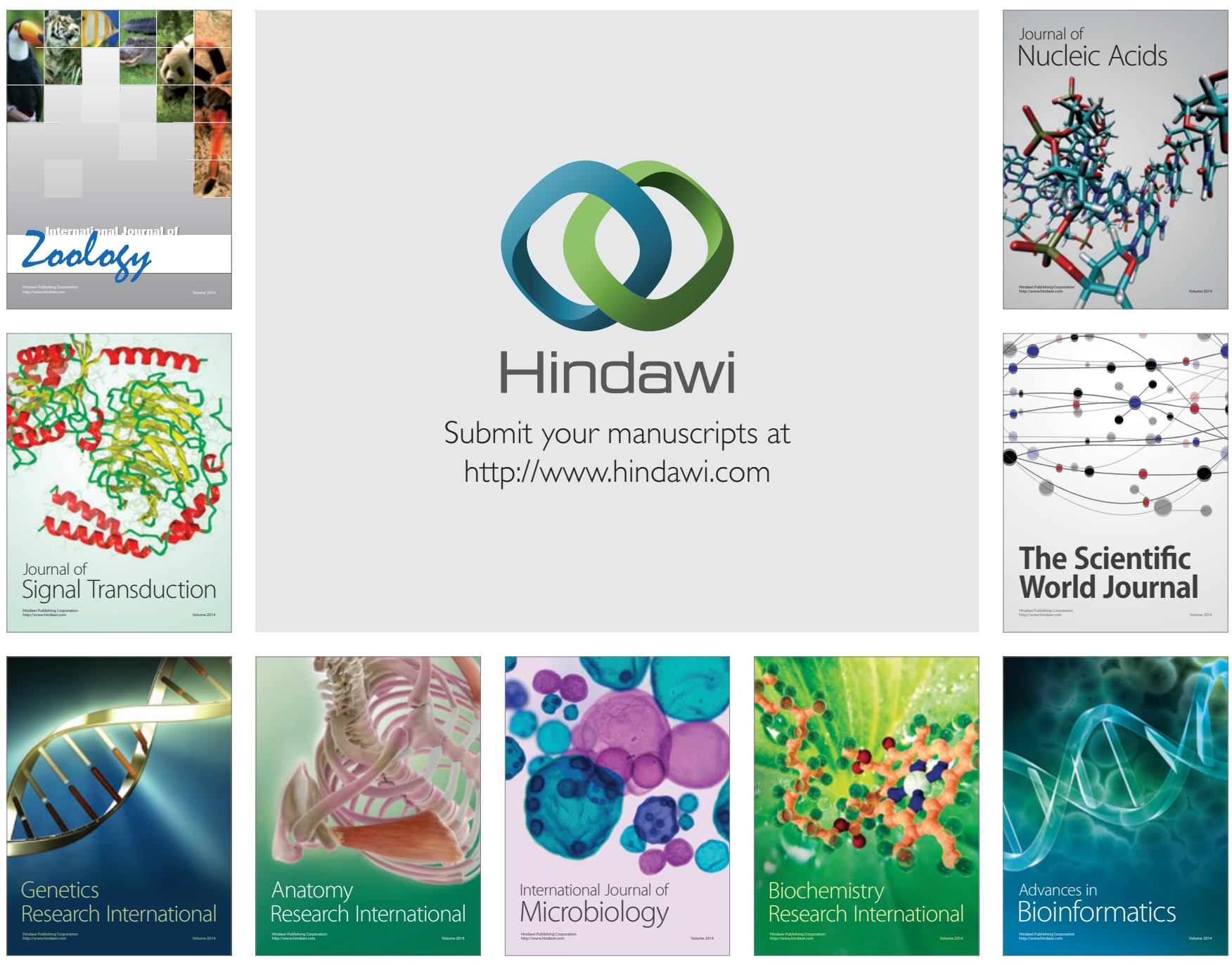

The Scientific World Journal
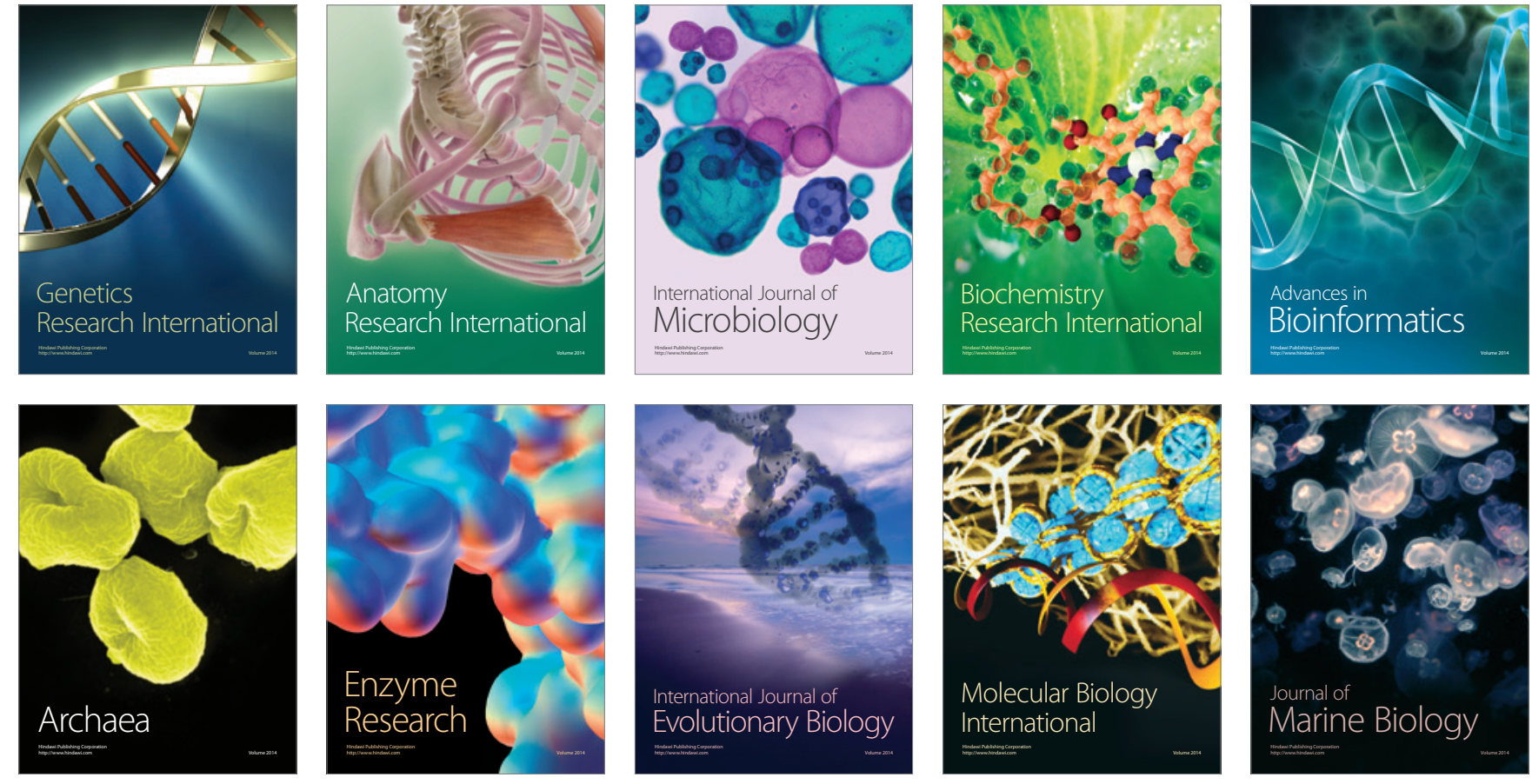